\title{
DIFFERENTIAL RESPONSE OF SOME EGYPTIAN COTTON VARIETIES TO BIO-BLEACHING TREATMENT
}

\section{BAHLOOL, SHEREEN OMAR}

Cotton Research Institute, ARC, Giza, Egypt

E-mail: dr_shereen_bahlool@yahoo.com

(Manuscript received 8 December 2013)

\begin{abstract}
In the present study, an attempt has been made to investigate the bio-bleaching preparation of Egyptian cotton fibers.

Bleaching of the fibers was performed with hydrogen peroxide, which was enzymatically produced by glucose oxidase during oxidation of $\mathrm{D}$-glucose.

The results obtained were compared with the conventional processing method. Promising results have been reported by Glucose Oxidase enzyme (Gox) that converts glucose to hydrogen peroxide and gluconic acid used for bleaching purpose. The gluconic acid produced is a good chelator and can be used as a sequestering agent for metal ions. This is so-called Indirect Enzymatic Bleaching Process and the whiteness degree obtained was acceptable compared with conventional chemical method. The mechanical properties such as tensile strength and elongation of cotton fibers showed no major influence using Gox compared with the conventional method.
\end{abstract}

Key words: Cotton Varieties, Bio-bleaching, Glucose oxidase

\section{INTRODUCTION}

Egyptian cotton is the world's finest cotton because it has some noble characteristics which set it apart from other natural fibers.[1]

The grayness of cotton is due to the natural pigments and matter present in the fibers. Raw cotton contains impurities such as complex organic compounds and complex substances. The purpose of cotton preparation is to remove the noncellulosic impurities from the cellulosic fibers and increase the wet ability and whiteness of the fabric. This improves dyeing performance and finishing. Conventional bleaching of cellulosic textiles use large amounts of chemicals, energy, and water. To avoid environmental damages, the effluents require neutralization or dilution prior to discharge. The greatest problem occurring during bleaching with peroxide is in the radical reactions of the bleaching compounds with the fiber which lead to a decline of polymerization and eventually to a decrease in tensile strength, especially in the presence of metal ions that act as activators for radical production (hydrogen peroxide).[2]

Because bioprocesses use living materials, they offer several advantages over conventional chemical methods of production: they usually require lower temperature, 
pressure, and $\mathrm{pH}$, they can use renewable resources as raw materials and greater quantities can be produced with less energy consumption. [3]

On analyzing the conventional bleaching process a very interesting phenomenon is noticed that with increase in temperature the stability of peroxide decreases rapidly in alkaline medium. The bleaching temperature that is used conventionally is around $100 \mathrm{C}$. At this temperature the peroxide is highly unstable. So in order to stabilize the peroxide an external stabilizer like Sodium Silicate should be added. It stabilizes the peroxide solutions considerably even at $\mathrm{pH}$ of 10 . It takes about $54 \mathrm{~min}$. for peroxide to decompose to extent of $50 \%$ in presence of silicate as a stabilizing agent. By this way the water hardness is removed from the solution. But this advantage is accompanied by a disadvantage that the calcium and magnesium silicates formed are sparingly soluble in water and get deposited on the surface of bleaching equipment leading to abrasion of fabrics and difficulty in washing off.[4-6]

The use of enzymes in textile industries started in the middle of $19^{\text {th }}$ century. Today the use of clean chemistry and green chemistry has trigged the use of enzymes because of the mild temperature and $\mathrm{pH}$ conditions that are required and their capability for replacing harsh organic/inorganic chemicals. Moreover, the wastewater effluent from enzymatic treatments is readily biodegradable and does not pose environmental pollutions. Peroxidase, laccase/mediator systems, glucose oxidase cellulase, hemicelluloase and catalase are examples of the enzymes that may be used in the bleaching process [7-11].

In this study, hydrogen peroxide was generated as a bleaching agent by means of enzymatic reactions. The production of $\mathrm{H}_{2} \mathrm{O}_{2}$ from glucose by glucose oxidase was investigated.

The most common bleaching agent nowadays is hydrogen peroxide, which is dosed in excess to the fibers. Alternatively, the peroxide could be produced in situ by enzymatic system glucose oxidase/glucose. $[12,13]$

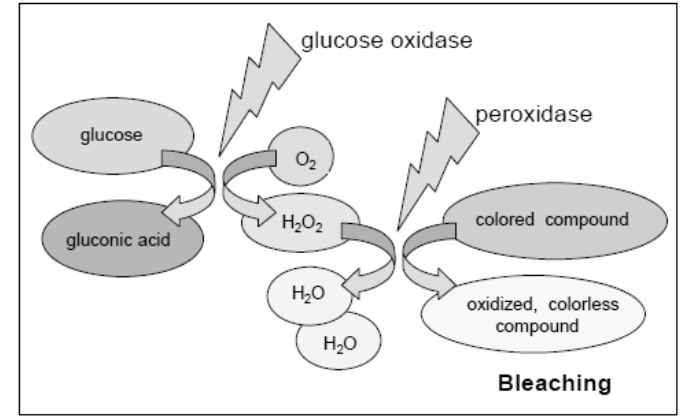

Figure 1. Use of oxidoreductases in bleaching processes. [3]

The implementation of enzymatic systems in the preparation of cotton is advantageous in terms of decreased water, chemicals and energy consumption, problems which have been reported concerning the maximum bleaching power of the peroxide. [14 ] 


\section{MATERIALS AND METHODS}

- Fibers

For this study fibers from four genotypes of Egyptian cotton varieties (Giza 93, Giza 88, Giza 80 and Giza 86) crop 2010 from Cotton Research Institute CRI, were used.

- Enzyme

Glucose oxidase enzyme was supplied by Novozymes Company and used for biobleaching.

- Chemicals

Sodium hydroxide; $\mathrm{NaOH}$, sodium chloride; $\mathrm{NaCl}$, sodium carbonate; $\mathrm{Na}_{2} \mathrm{CO}_{3}$ ， hydrogen peroxide; $\mathrm{H}_{2} \mathrm{O}_{2}$, sodium silicate; $\mathrm{Na}_{2} \mathrm{SiO}_{3}$, magnesium chloride; $\mathrm{MgCl}_{2} 6 \mathrm{H}_{2} \mathrm{O}, \mathrm{D}(+)$ glucose and non-ionic wetting agent; Triton $\mathrm{X}-100$

\section{- Bleaching Process}

\section{a) Conventional Bleaching.}

The scoured fibers were bleached in bath containing: $1.5 \mathrm{~g} / \mathrm{l}$ sodium hydroxide, $0.4 \mathrm{~g} / \mathrm{l}$ sodium silicate, $0.2 \mathrm{~g} / \mathrm{l}$ sodium carbonate, $0.2 \mathrm{~g} / \mathrm{l}$ magnesium sulphate, and $25 \mathrm{ml} / \mathrm{l}$ $35 \%$ hydrogen peroxide. The liquor ratio was 1:50 at boiling for 90 minutes. The samples were finally thoroughly washed with hot water followed by cold water.

\section{b) Bio-bleaching: Enzymatic}

The scoured samples of four Egyptian cotton fibers were bleached with liquor ratio of 1:20 using Glucose oxidase enzyme, with different enzyme concentrations $(0.25,0.50$, $1,2 \mathrm{~g} / \mathrm{l})$, and D-glucose $(10 \mathrm{~g} / \mathrm{l})$ at neutral $\mathrm{pH} 7$ and $40{ }^{\circ} \mathrm{C}$ for 60 minutes.

Afterward the $\mathrm{pH}$ was changed to alkaline 10 and the temperature raised to $85^{\circ} \mathrm{C}$. The fibers were then rinsed, and the enzyme solution discarded.[7]

\section{Testing and Analysis}

\section{Tensile strength and elongation percentage}

Fiber tenacity (flat bundle tensile strength) and elongation (extension to break) were determined on the Stelometer Strength - Elongation tester according to ASTM standards D: 1445-1967, at the fiber testing Lab., Cotton Research Institute.

\section{Whiteness and yellowness index}

These were measured using the double beam spectrophotometer (Perkin Elmer Company -USA, of model Lambda 35). The measurement was done in accordance to ASTM E313-96 using CIE color system coordinates.

\section{The image analysis}

Computer image analysis system provided by Leica Company was used for the morphological investigation of the fibers before and after treatment.[22] 


\section{RESULTS AND DISCUSSION}

\section{Hydrogen peroxide bleaching:}

Hydrogen peroxide is a very weak acid. It could be ionized to form hydroperoxy ions (HOO-)

$$
\begin{array}{ccc}
\mathrm{H}_{2} \mathrm{O}_{2} & \Leftrightarrow & \mathrm{HOO}-+\mathrm{H}+ \\
\mathrm{HOO}- & \Leftrightarrow & \mathrm{OH}-+[\mathrm{O}]
\end{array}
$$

The formation of the active hydroperoxy ions is favored by alkaline conditions and these anions are the source of the active oxygen that has the bleaching effect. [3]

\section{Enzymatic bleaching:}

In enzymatic bleaching the following reaction takes place:

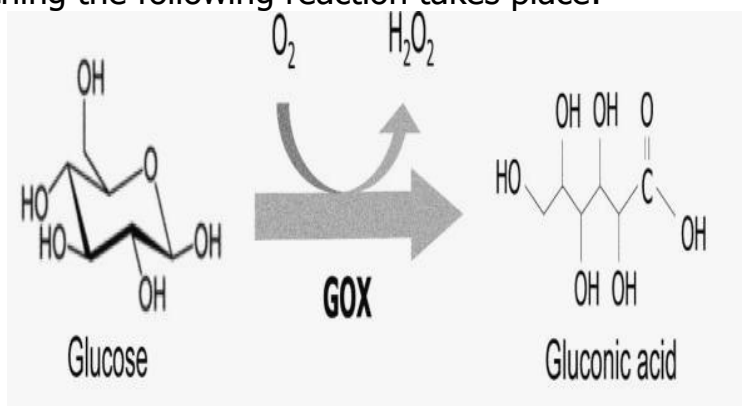

Figure 2. Enzymatic generation of $\mathrm{H}_{2} \mathrm{O}_{2}$ by glucose oxidase(GOX). [4]

The enzyme is highly specific for B-D-glucose and catalyzes the following reaction for

hydrogen peroxide generation at $\mathrm{pH}-4.5-7$ and temperatures of around $40^{\circ} \mathrm{C}$.[15] Glucose oxidase enzyme catalyzes the oxidation of glucose units to gluconic acid and hydrogen peroxide simultaneously in the presence of oxygen. $[16,17]$

The gluconic acid produced in the enzyme reaction acts as a chelating agent for metal ions. However, there is still no bleaching process based on enzymatic peroxide generation, which has found industrial application. $[12,13]$

\section{Effect of Enzyme concentrations on Tensile strength and Elongation of} Egyptian cotton fibers

It has been found as shown in Figures 3 and 4 that there is a mild decrease in tensile strength with increasing the Gox enzyme concentration due to increase of hydrogen peroxide produced from the enzyme. It was noticed that there is a different response shown in fiber elongation percent due to the cotton variety. 
Tensile Strength (g/tex)

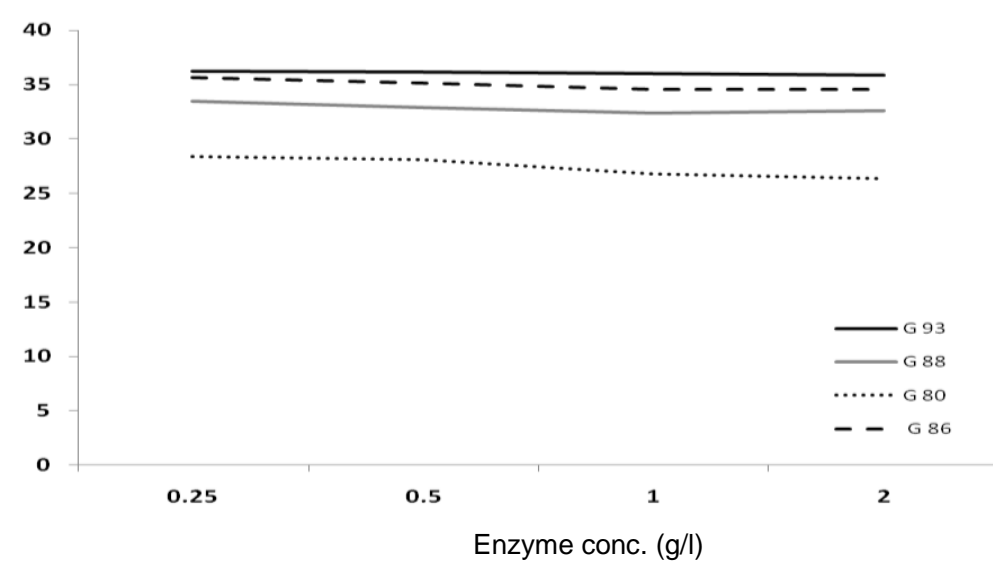

Figure. 3. Effect of Enzyme conc. on Tensile strength of Egyptian cotton fibers

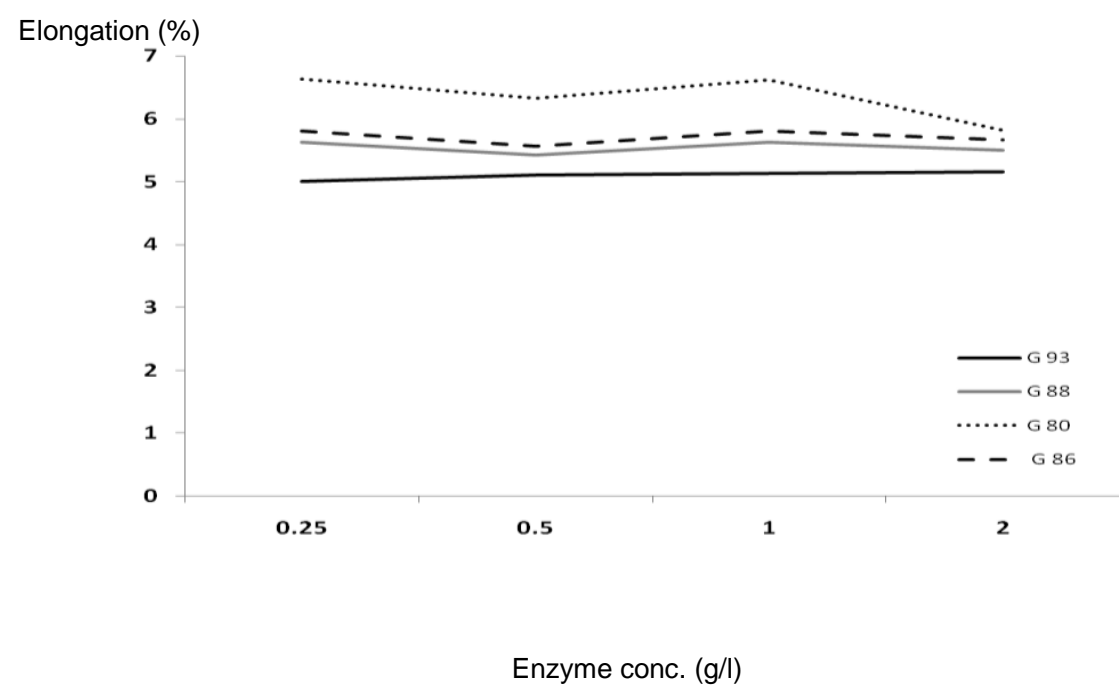

Figure.4. Effect of Enzyme conc. on Elongation of Egyptian cotton fibers

\section{Effect of Enzyme concentrations on Whiteness and Yellowness index of Egyptian cotton fibers}

It is apparent from Figures 5 and 6 that the whiteness values were greater for the samples treated with higher enzyme concentrations than the samples treated at lower concentrations in the bleaching process. Similarly, the higher concentrations of $\mathrm{H}_{2} \mathrm{O}_{2}$ brought more brightness and less yellowness as expected. 
Yellowness index

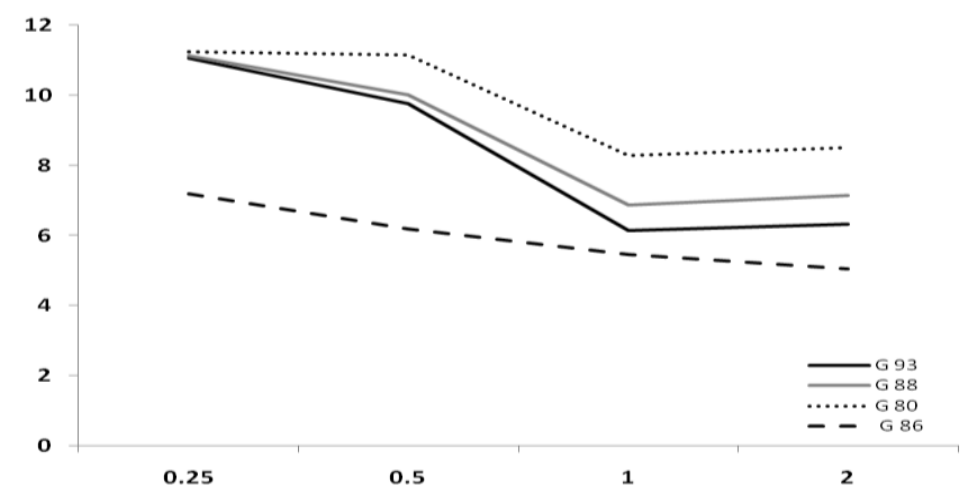

Enzyme conc. $(g / l)$

Figure.5. Effect of Enzyme conc. on Yellowness index of Egyptian cotton fibers

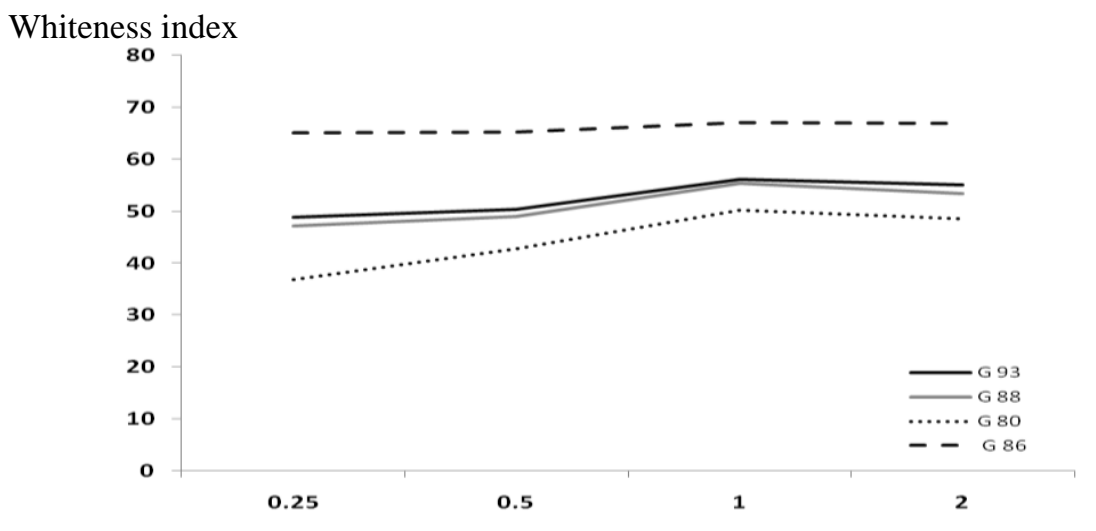

Enzyme conc. (g/l)

Figure.6. Effect of Enzyme conc. on Whiteness index of Egyptian cotton fibers

\section{Comparison between the conventional and Bio-bleaching processes}

Tensile strength, Elongation, whiteness index and yellowness index of different chemical treatments are given in table 1 . The measurements represent a comparison between the conventional bleaching and bio-bleaching using $1 \mathrm{~g} / \mathrm{l}$ Glucose oxidase enzyme. 

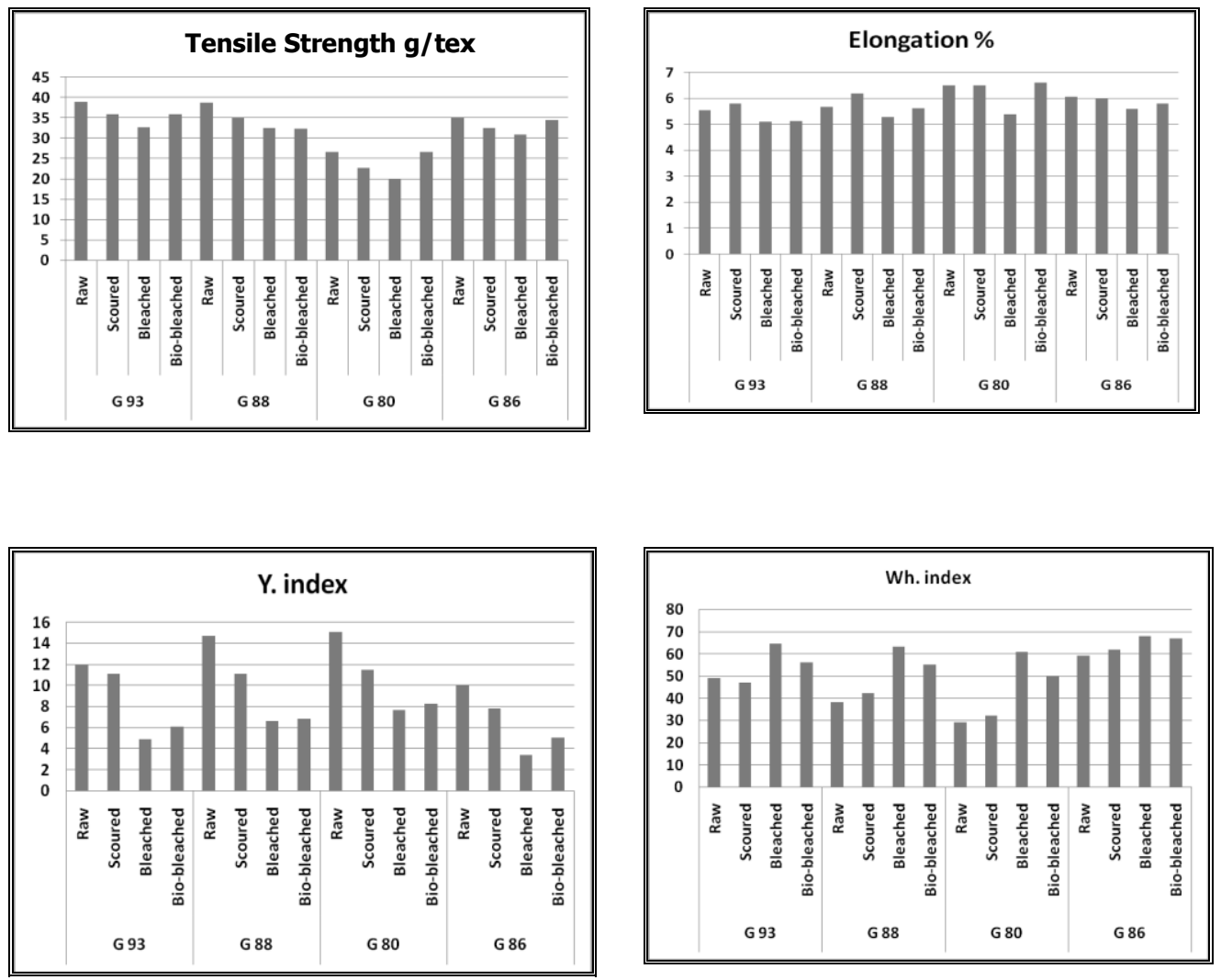

Figure.7. Effect of conventional and Bio-bleaching process on Properties of Egyptian cotton fibers

The results illustrated by Figure 7 show the comparison between the conventional $\mathrm{H}_{2} \mathrm{O}_{2}$ bleaching and Enzymatic Bio-bleaching process. The bio bleached samples showed better mechanical properties such as higher tensile strength and elongation percent than those chemically bleached samples in all used Egyptian cotton varieties. Although the whiteness index was better for the chemically bleached samples, it was quite acceptable for the bio-bleached samples as well. 


\section{Morphological Structure of the cotton fibers treated with conventional bleaching and Bio-bleaching processes}

Determination of fiber fineness and maturity from dry fiber using image analysis technique
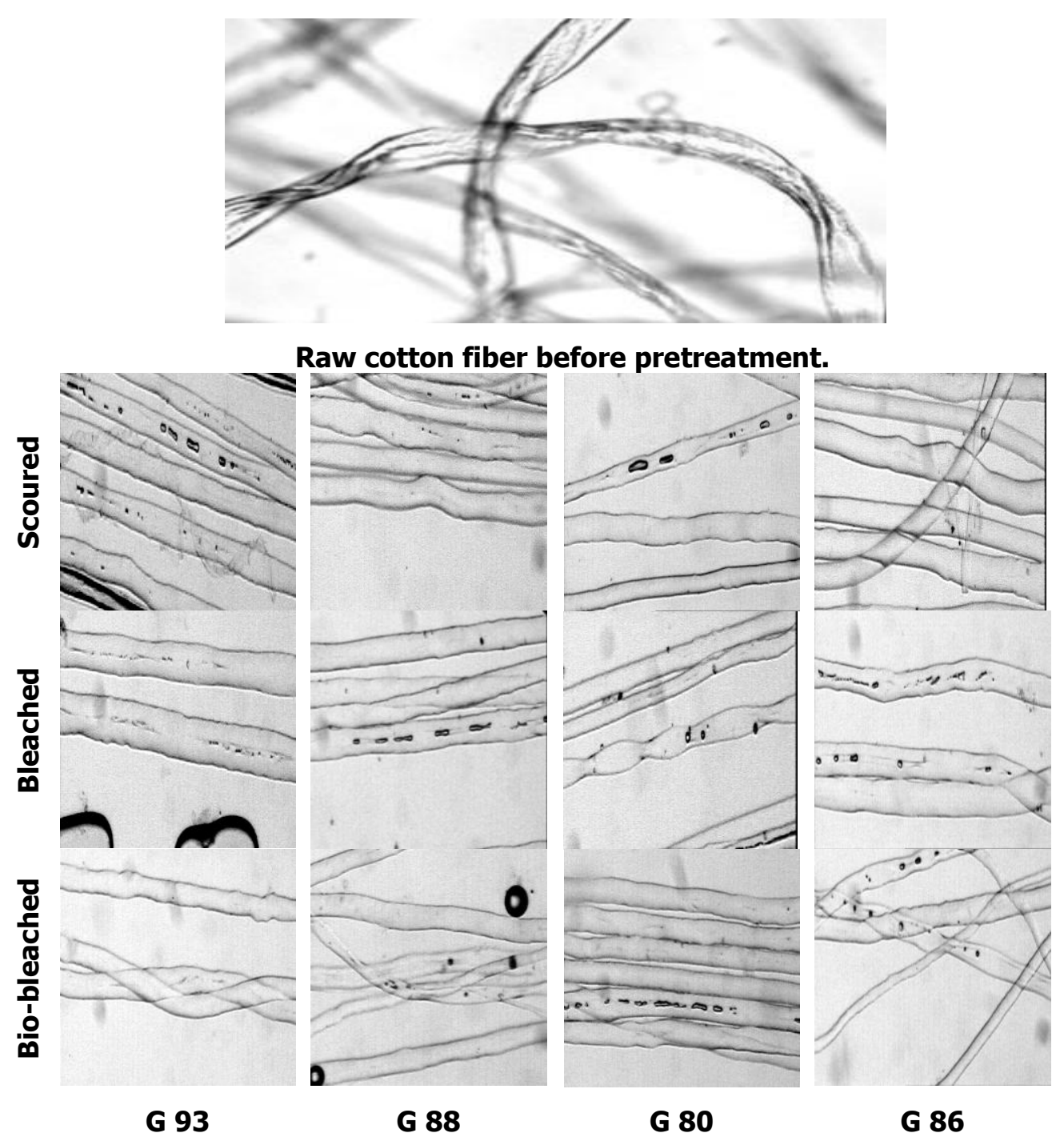

Figure.8. Morphological Structure of the cotton fibers

Figure 8 shows the morphological structures of the fibers before and after treatment. Dry fiber ribbon width ranged in the studied cotton genotypes from $16.4 \mu$ for G93 to $18.7 \mu$ for G80.

The results reveal a relationship with diameter value, maturity ratio, while didn't show any relationship with other fiber quality properties. The image analysis of the fibers showed different morphological structure of raw and treated fibers of various cotton genotypes. 
It is well known that the spiral growth of cotton cell-hairs is analogous to the tension of a spring with a SZ-spiral structure, due to the internal stresses of the cellular wall and clockwise rotation. It has been shown that microtubules with a diameter of about 5 $\mathrm{nm}$ have the shape of a twisted spring and directly influence the orientation of the microfibrils of cotton cellulose and the cellular wall organization.

The spiral structures of cotton hairs are well revealed by chemical processing, first causing the hair to swell. The spiral tubular structures can be placed as in surface layers, and they can occupy the full thickness of the cellular wall. The increased dimensions of microfibril are related to the swelling of cellulose and to the treatment of cotton fiber preparation. [18-20]

\section{CONCLUSION}

The advantage of enzymatic treatment in the preparation of cotton is decreased water, chemicals, and energy consumption. Enzymes are used in textile industries because they: accelerate reactions; act only on specific substrates by lowering the activation energy for the reaction, Operate under mild conditions, are safe and easy to control. They can replace harsh chemicals and are biodegradable [21]. The peroxide is the most famous bleaching agent used in industry but it could be produced in situ by enzymatic system using glucose oxidase.

From this study, It can be concluded that with an increase in enzyme concentration the whiteness of cotton fibers was improved to be close to those cotton fibers treated with conventional $\mathrm{H}_{2} \mathrm{O}_{2}$ bleaching processes, CIE Whiteness obtained was acceptable with integrated method when compared with conventional method.

The measurements of mechanical properties such as tensile strength and elongation of cotton fibers showed no major influence using Gox compared with conventional method.
Abbreviations
$\mathrm{GOx}=$ Glucose Oxidase enzyme
$\mathrm{H}_{2} \mathrm{O}_{2}=$ Hydrogen Peroxide
Wh. index $=$ Whiteness index
Y. index $=$ Yellowness index
G $88=$ Giza 88 (Egyptian Cotton variety)
G 86= Giza 86 ( Egyptian Cotton variety )
G $80=$ Giza 80 ( Egyptian Cotton variety )
G 93= Giza 93 ( Egyptian Cotton variety ) 
Table 1. Comparison between the conventional bleaching and Bio-bleaching

\begin{tabular}{|c|c|c|c|c|c|c|c|c|c|c|}
\hline \multicolumn{2}{|c|}{ Variety } & \multirow{2}{*}{$\begin{array}{l}\text { Treatment } \\
\text { Raw }\end{array}$} & \multirow{2}{*}{$\begin{array}{r}\text { Y. index } \\
11.94\end{array}$} & \multirow{2}{*}{$\begin{array}{c}\text { Wh. index } \\
48.99\end{array}$} & \multirow{2}{*}{$\begin{array}{c}\text { Tensile Strength } \\
\text { g/tex } \\
38.95\end{array}$} & \multirow{2}{*}{$\begin{array}{c}\text { Elongation \% } \\
5.55\end{array}$} & \multirow{2}{*}{$\begin{array}{c}\text { Diameter } \mu \\
16.35\end{array}$} & \multirow{2}{*}{$\begin{array}{c}\text { Maturity \% } \\
73.60\end{array}$} & \multirow{2}{*}{$\begin{array}{c}\text { Convolution No. } \\
\text { per mm. } \\
3.325\end{array}$} & \multirow{2}{*}{$\begin{array}{c}\begin{array}{c}\text { Reversals } \\
\text { No. per } \\
\text { mm. }\end{array} \\
1.375\end{array}$} \\
\hline & G 93 & & & & & & & & & \\
\hline \multirow{3}{*}{ 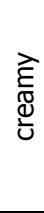 } & & Scoured & 11.14 & 47.04 & 35.99 & 5.8 & 16.60 & 64.35 & 3.165 & 1.210 \\
\hline & & Bleached & 4.9 & 64.78 & 32.79 & 5.1 & 16.12 & 61.00 & 2.890 & 1.340 \\
\hline & & $\begin{array}{l}\text { Bio-bleached GOX } \\
\text { enzyme-1.0 g/l, }\end{array}$ & 6.15 & 56.18 & 35.99 & 5.14 & 16.88 & 71.80 & 3.235 & 1.200 \\
\hline \multirow{4}{*}{ 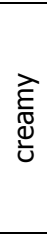 } & \multirow[t]{4}{*}{ G 88} & Raw & 14.75 & 38.45 & 38.78 & 5.69 & 17.44 & 77.10 & 3.59 & 1.210 \\
\hline & & Scoured & 11.16 & 42.21 & 35.04 & 6.2 & 18.05 & 73.95 & 3.365 & 1.375 \\
\hline & & Bleached & 6.67 & 63.54 & 32.61 & 5.3 & 18.70 & 62.75 & 3.225 & 1.290 \\
\hline & & $\begin{array}{l}\text { Bio-bleached GOx } \\
\text { enzyme-1.0 g/l, }\end{array}$ & 6.88 & 55.37 & 32.35 & 5.63 & 18.57 & 76.40 & 3.455 & 1.275 \\
\hline \multirow{4}{*}{ 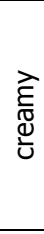 } & \multirow[t]{4}{*}{ G 80} & Raw & 15.12 & 29.3 & 26.74 & 6.51 & 18.65 & 74.90 & 3.170 & 1.085 \\
\hline & & Scoured & 11.48 & 32.3 & 22.81 & 6.5 & 19.75 & 72.75 & 3.105 & 1.155 \\
\hline & & Bleached & 7.71 & 60.99 & 20.06 & 5.4 & 19.10 & 66.35 & 3.020 & 1.145 \\
\hline & & $\begin{array}{l}\text { Bio-bleached GOx } \\
\text { enzyme-1.0 g/l, }\end{array}$ & 8.28 & 50.14 & 26.73 & 6.62 & 19.12 & 73.65 & 3.465 & 1.175 \\
\hline \multirow{4}{*}{$\frac{9}{\frac{4}{3}}$} & \multirow[t]{4}{*}{ G 86} & Raw & 10.13 & 59.34 & 35.16 & 6.07 & 17.75 & 76.00 & 3.280 & 1.255 \\
\hline & & Scoured & 7.87 & 62.19 & 32.61 & 6 & 18.25 & 73.80 & 3.160 & 1.265 \\
\hline & & Bleached & 3.47 & 68.01 & 30.88 & 5.6 & 18.60 & 70.50 & 3.055 & 1.230 \\
\hline & & $\begin{array}{l}\text { Bio-bleached } \\
\text { enzyme-1.0 g/l, }\end{array}$ & 5.05 & 67 & 34.56 & 5.8 & 18.65 & 74.70 & 3.190 & 1.205 \\
\hline
\end{tabular}




\section{REFERENCES}

1. Mahmood, N., Tusief, M.Q., Arshad, M., \& Azeem, M. 2010. Physico-chemical study of Egyptian and common wealth of independent states(CIS) long staple cotton and spinning potential evaluation at ring and compact spinning systems under some mechanical variables. Pakistan Journal of Science, 62, 2-9.

2. Ahvenainen, J. 2000. "White Cotton Bio-bleaching Saves Costs and Nature". (VTT) Technical Research Centre Of Finland, p1-2.

3. Hossain, S., \& Uddin, K. 2011. Comparative Analysis between Conventional Pretreatment and Biopreparation. International Journal of Engineering \& Technology, 11, 16-21.

4. Menezes, E \& Choudhari, M. 2011. Pre-treatment of Textiles Prior to Dyeing. Textile Dyeing, Hauser, P (Ed.). ISBN: 978-953-307-565-5. InTech. 232-239.

5. Opwis, K., Knittel, D., \& Schollmeyer, E. 2008. Use of Enzymes in the PreTreatment of Cotton. Deutsches Textilforschungszentrum Nord-West e.V., Adlerstr. 1, D-47798 Krefeld, Germany, p.1-8.

6. Lopez, C., \& Cavaco-Paulo, A. 2008. In-situ Enzymatic Generation of Hydrogen Peroxide for Bleaching Purposes, Eng. Life Sci, 8, 315-323.

7. Ramadan, A.R. 2008. Characterization of Biobleaching of Cotton/Linen Fabrics. Journal of Textile and Apparel, Technology and Management (JTATM), 6, 1-12.

8. Anis, P., \& Eren, H.A. 2002. Examining the effectiveness and the environmental impact of rinsing in reactive dyeing. American Association of Textile Chemists and Colorists, AATCC review, 2, 22-26.

9. N. Sekar. 2001. Peracetric acid bleaching - an environmentally safe alternative: an update, Colourage, , Jan. 2001, Vol. 48 Issue 1, p35

10. N. P. Jensen. 2001. American Association of Textile Chemists and Colorists (AATCC), 1, 23.

11. Tznanov T. ,Costa S. \& Pauls A. 2001. American Association of Textile Chemists and Colorists, AATCC Review, vol. 1, No.10, 25.

12. Tzanov T., Calafell M., Georg , Guebitz M. and Paulo A. 2001. Bio-preparation of cotton fabrics. Enzyme and Microbial Technology, 29, 357-362.

13. Saravanan D. , Vasanthi N S, Raja K S, Arunava D. and Ramachandran T. 2010. Bleaching of cotton fabrics using hydrogen peroxide produced by glucose oxidase. Indian J. of fiber and textile Res, 35, 281-283

14. Diller G. B. 2001. Environmentally Benign Preparatory Processes. Introducing a Closed-Loop System. National Textile Center Annual Report: C99-A07, November, 1-10. 
15. Sundar P S, Bhatoye S K, Karthikeyan N \& Prabhu K H. 2007. Enzyme applications in textiles. Indian Textile Journal, May 2007 , p.1-7 .

16. Diller G B, Yang X D and Yamamoto R. 2001. " Enzymatic Bleaching of Cotton Fabric with Glucose Oxidase ", Textile Research Journal, 71 , May, 388-394.

17. Ali S., Khatri Z \& Tanwari A. 2011. "Integrated Preparatory Method for Cotton Towel by Using Enzymes ", Inter. J. Chemi.\& Enviro. Eng., October, Vol 2, No.5, 295-301

18. Krakhmalev V.A. \& Paiziev A.A. 2006. " Spiral structures of cotton fiber", Cellulose, vol. $13,45-52$

19. Seagull R.W. 1986. "Changes in microfibrile organization and wall microfibril orientation during in-vivo cotton fiber development: an immunofluorecent study" , Can. J. Bot., vol. 64, , 1373-1381.

20. Lioyd C. and Chan J. 2002. "Helical microtubule arrays and spiral growth", Plant Cell, vol. 14, 2319-2324.

21. Haggag K., Ragheb A.A., Abd EL-Thalouth I., Nassar S.H. \& EL-Sayed H. 2013. " A review Article on Enzymes and Their Role in Resist and Discharge Printing Styles", Life Science J., vol. 10 (1) , 1646-1654

22. Ghith A., Fayala F.\& Abdeljelil R. 2011." Assessing Cotton Fiber Maturity and Fineness by Image Analysis ", Journal of Engineered Fibers and Fabrics , Volume 6 , Issue 2 , p.50-60 


\title{
اختلاف استجابة بعض اصناف القطن المصري لعملية التبيضض الحيوي
}

\author{
شيرين عمر بهول \\ قسم بحوث كبياء القطن وألياف النسيج - معرج بحوث القطن
}

تتضمن هذه الدراسة اجر اء عملية التحضير ات و التبييض الحيوي لألياف القطــن المصــرى ،

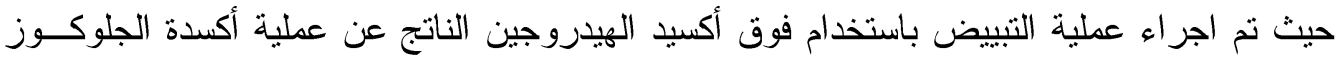
باستخدام أنزيم جلوكوز أكسيديز. وتم عقد مقارنة بين نتائج كلا من الطريقة التقليدية وطريقة التبييض الحيوي باســتخدام انـزيم

$$
\text { جلوكوز أكسيديز ، و الذى أظهر نتائج مبشرة. }
$$

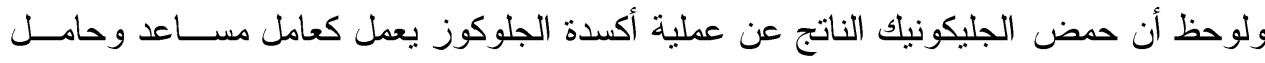

للايونات المعدنية فى وسط عملية التبييض وهذه العملية تسمى التبييض الحيوى غير المباشر.

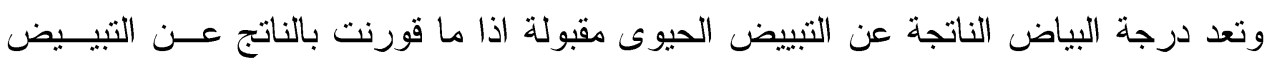
التقليدى الكيميائى خاصة مع الاخذ فى الاعتبار باقى الخواص الميكانيكية من متانة و استطالة لالياف

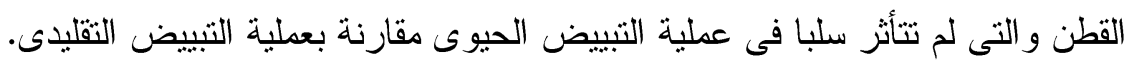

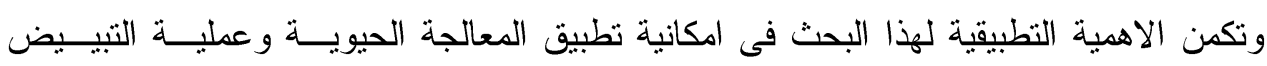

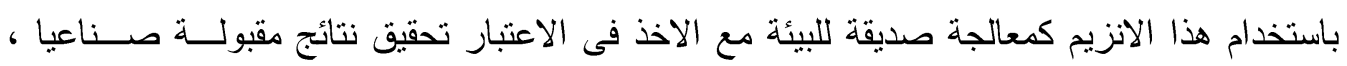

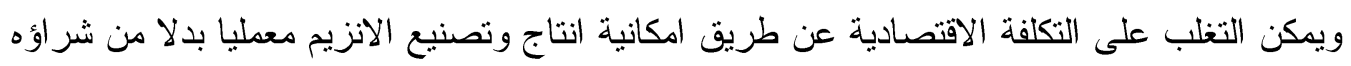
• وبهذا يتحقق البعد البيئى مع البعد الاقتصادى . 